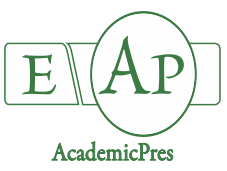

Pierozzi NI and Fernandes Moura M (2021)

Notulae Botanicae Horti Agrobotanici Cluj-Napoca

Volume 49, Issue 2, Article number 11975

DOI: $10.15835 /$ nbha49211975

Research Article

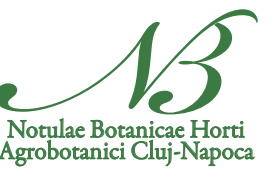

\title{
Evaluation of mitotic activity in tapetal cells of grapevine (Vitis L.)
}

\author{
Neiva Izabel PIEROZZI ${ }^{1 *}$, Mara FERNANDES MOURA² \\ ${ }^{1}$ Instituto Agronômico de Campinas (IAC), Centro de Recursos Genéticos Vegetais, 1481 Barão de Itapura Ave., Campinas, \\ Brazil; neiva.pierozzi@sp.gov.br (*corresponding author) \\ ${ }^{2}$ Instituto Agronômico de Campinas (IAC), Centro Avançado de Pesquisas de Frutas, 1500 Luís Pereira dos Santos Ave., Jundiaí, \\ Brazil; mara.moura@sp.gov.br
}

\begin{abstract}
The knowledge with reference to the grapevine tapetum has been centered on its anatomy/morphology and hardly anything at all is known about its mitotic activity throughout the microsporogenesis. The aim of this study was to ascertain the mitotic activity in tapetal cells of some grapevines (Vitis L.) broadening knowledge about this tissue and simultaneously corroborating the viability of its use as an alternative tissue for further cytogenetic studies. Young buds of 12 grapevine varieties at different meiotic stages were squashed and tapetal cells a prometaphase/metaphase scored in each meiotic stage. Mitotic activity was observed since the beginning of microsporogenesis, where it was more intense, decreasing toward tetrad. Polyploid tapetal cells arose through endomitosis while the microsporogenesis advanced. Two types of polyploid cells were evidenced, those with two or more individualized diploid chromosome groups and those with only one polyploid group. The percentage of diploid cells and of polyploid cells with two or more individualized diploid groups was higher during the first stage of microsporogenesis, though decreasing and giving way to cells with one large polyploid group as microsporogenesis moved toward tetrad. The nucleolus number was scored at interphase at different stages. Two and four nucleoli prevailed in tapetal cells at all stages except at tetrad where one large nucleolus was seen. The results showed that despite of the squashing technique applied, grapevine tapetum has a substantial amount of cells with mitotic activity with a satisfactory chromosome spreading therefore establishing an interesting alternative and promising tissue for later cytomolecular studies.
\end{abstract}

Keywords: grapevine varieties; mitotic activity; mitotic chromosomes; tapetum; Vitis

\section{Introduction}

The male gametogenesis in flowering plants occurs in the anther, a stamen-specialized structure, which comprises different types of tissue as epidermis, middle layer and tapetum. Among these, tapetum is the innermost tissue in direct contact with the sporogenous tissue, i.e., the pollen mother cells (PMCs). Its main function is the nourishment of male reproductive cells, playing a key role in the process of microsporogenesis through the synthesis and transport of nutrients, proteins, polysaccharides, lipids and regulatory compounds. The development of the tapetum is highly regulated from its onset to the end through a programmed cell death (PCD) constituting a complex gene regulatory network (Li et al., 2017). The impairing of its adequate development or a delay in tapetum PCD or premature tapetum degeneration is enough to cause disturbance in

Received: 19 Jun 2020. Received in revised form: 07 May 2021. Accepted: 24 May 2021. Published online: 03 Jun 2021.

From Volume 49, Issue 1, 2021, Notulae Botanicae Horti Agrobotanici Cluj-Napoca journal uses article numbers in place of the traditional method of continuous pagination through the volume. The journal will continue to appear quarterly, as before, with four annual numbers. 
the microsporogenesis and pollen sterility (Zhai et al., 2015; Liu et al., 2018). Several transcription factors and genes have been reported to be associated with the proper tapetum development and degeneration. Studies developed in the model plant Arabidopsis thaliana demonstrated that the mutation in members of LLR receptor kinase EMS1signaling complex resulted in impairing tapetal cells proliferation (Feng and Dickinson, 2010) while the mutant gene msl caused a delay of tapetum degeneration (Quilichini et al., 2014) and the mutant gene myb80gave rise to a precocious tapetum degeneration (Zheng et al., 2016). In rice, it was observed that the transcription factor EAT1 positively regulated the tapetum PCD and triggers the phasiRNA biogenesis that was exported to PMCs during early meiosis. The data obtained also suggested that the phasiRNAs might be involved in microsporocyte chromosome condensation and accurate chiasma formation during meiosis (Ono et al., 2018; Lei and Liu, 2020). While the microsporogenesis process continues, the tapetal cells undergo epigenetic changes as an increase in DNA methylation and high chromosome condensation along with the reorganization of the nucleus architecture, including the nucleolus (Solís et al., 2013).

During the meiotic process up to tetrad phase, the tapetal cells also endure cellular polyploidization through endomitotic cycles increasing chromosome number and enlarging cell size before its degeneration. Witkus (1945) while carrying out the first description of the endomitosis phenomenon in tapetal cells of spinach realized the significance of this mechanism for cell growth and enlargement of this tissue. Other researches using other plant materials as tomato (Brown, 1949), Eremurus himalaicus (Oksala and Therman, 1977) and some Cymbidium species (Sharma et al., 2012), for instance, confirmed this phenomenon. Tapetal cells that suffer endomitosis have their replicated chromosomes condensed, however, without going through cytokinesis (Matsunaga et al., 2013). A cell structure, the phragmoplast, which serves as a scaffold to cell plate assembly, is not structured thus impairing cytokinesis. Therefore, two or more distinct diploid chromosome groups can remain separate in the same cell and depending on the cytological technique employed, it might possible to visualize the nuclear membrane around the chromosome groups. Sometimes two or more diploid chromosome groups of a cell tend to fuse at metaphase or at anaphase as a restitution nucleus giving rise to just one polyploid group (Oksala and Therman, 1977).

In the genus Vitis the studies in tapetal cells began with Dorsey's investigations about male sterility in some grapevines with a description of anther anatomy of 'Brighton' an interspecific hybrid variety ( $V$. vinifera X V. labrusca) (Dorsey, 1914). This author provided the first description of grape tapetum observing it was organized in a single cell layer, which was later confirmed by Büyükkartal et al. (2005) and classified as parietal also known as secretory or glandular type (Pacini, 1997). Dorsey's cytological findings preceded the establishment of the diploid chromosome number in Vitis genus that was done by Ghimpu (1929) who counted $2 n=38$ for $V$. labrusca, V. riparia and $V$. vinifera and by Nebel (1929) who confirmed $2 n=38$ for some Vitis vinifera varieties. Later, Branas (1932) counted $2 n=40$ for the American species $V$. rotundifolia. The origin of these two different chromosome numbers in the genus, i.e., $2 n=38$ and $2 n=40$ has intrigued some researches about its origin. However, refined studies recently carried out by Cochetel et al. (2021) in Muscadinia rotundifolia ( $n=20$ ) [Vitis rotundifolia Michx., syn. Muscadinia rotundifolia (Michx.) Small., according to The Plant List (2013); Hickey et al. (2019)] and V. vinifera 'Cabernet Sauvignon' ( $n=19)$ using a Single-molecule real-time reads combined with optical maps technique demonstrated that, in the past, there could have been a reduction in chromosome number by a fusion process involving chromosomes 7 and 20 in the ancestor of $V$. rotundifolia which gave rise to the ancestor of Vitis species with $n=19$. From then on, the two chromosome groups evolved independently.

The cytological works on some Vitis species and varieties have been predominantly centered on chromosome number (Olmo, 1937; Takusagawa, 1952; Shetty and Raman, 1960) and few attempts were done to describe chromosome morphology for the obtainment of karyotypes (Raj and Seethaiah, 1969, 1973; Patil and Patil, 1992). Also, studies on constitutive heterochromatin localization and characterization at the cytochemical level, using fluorescent dyes (Pinto-Maglio et al., 2010), mapping of rDNA 45S loci through in situ hybridization (Castro et al., 2018) as well as the active NOR sites localization (Pierozzi, 2011) have been done. Besides, there have been studies to ascertain the regularity of microsporogenesis process and the pollen 
fertility percentage of some diploid grapevine varieties and hybrids of interest in breeding programs as well as of some spontaneous and induced tetraploid varieties (Patel and Olmo, 1955; Viljoen and Spies, 1995; Kuliyev, 2020).

However, hardly anything at all is known about mitotic activity of grapevine (Vitis) tapetal cells from the first meiotic phases to young pollen grain stage. Hence a study was carried out in the tapetum of some grapevine varieties to ascertain: (a) the degree of mitotic activity in tapetum during microsporogenesis, amplifying cytological knowledge about this tissue; (b) if chromosome at late prometaphase and metaphase have a satisfactory spreading, allowing further use of tapetal cells in advanced cytomolecular studies; (c) if during the microsporogenesis process the cells at interphase of this secretory and nutrition tissue show any alteration in nucleolus number and/or size.

\section{Materials and Methods}

\section{Biological material}

Six seedless diploid $(2 n=38)$ varieties of Vitis vinifera 'A Dona' 'Black Corinth', 'Einset', 'Golden Muscat', 'Maria', 'Venus' and other five diploid varieties of 'Niagara' ( $V$. vinifera $2 n \times V$. labrusca) 'Niagara 'Branca' ('White Niagara'), 'Niagara Rosada' ('Rosy Niagara'), 'Niagara Rosada sem Semente' ('Seedless Rosy Niagara'), 'Niagara Steck' ('Steck Niagara') and 'Niagara Variegada' ('Variegated Niagara') were considered in this study. Besides, one spontaneous somatic autotetraploid of 'Niagara Rosada', 'Niagara Rosada Gigante' ('Giant Rosy Niagara') ( $2 n=76$ ), was added totaling 12 varieties. All the varieties belong to Vitis IAC (Instituto Agronômico de Campinas) germplasm collection at the Fruit Center in the city of Jundiaí, state of São Paulo. They were introduced to IAC grapevine collection from some European countries and from the USA at different times over the last Century. The pedigree of each variety studied as well as the chromosome numbers are summarized in Table 1.

Table 1. Pedigree of each grapevine variety studied and the diploid chromosome number $(2 n)$

\begin{tabular}{|c|c|c|}
\hline Varieties studied & $2 n$ & Pedigree* $^{*}$ \\
\hline \multicolumn{3}{|l|}{ a. Vitis vinifera varieties ${ }^{1}$ : } \\
\hline 'A Dona' & 38 & $\begin{array}{c}\text { ('Highland' x ‘Golden Queen') × ('Pirovano 57’ × 'Muscat of } \\
\text { Alexandria') }\end{array}$ \\
\hline 'Black Corinth' & 38 & $V$. vinifera old European seedless variety \\
\hline 'Einset' & 38 & 'Fredonia' $\times$ 'Canner' ('Hunisa' $\times$ 'Sultanina') \\
\hline 'Golden Muscat' & 38 & 'Muscat Hamburg' X 'Diamond' \\
\hline 'Maria' & 38 & ('Highland' × 'Golden Queen') × 'Jumbo seedless' \\
\hline 'Venus' & 38 & 'Alden' × 'NY 46000' \\
\hline \multicolumn{3}{|l|}{ b. 'Niagara' varieties: } \\
\hline 'Niagara Rosada' ('Rosy Niagara')2 & 38 & $($ V. labrusca $\times V$. vinifera $) \times V$. labrusca \\
\hline 'Niagara Branca' ('White Niagara') & 38 & 'Niagara Rosada' spontaneous somatic mutation \\
\hline $\begin{array}{l}\text { 'Niagara Rosada Gigante' ('Giant Rosy } \\
\text { Niagara') }\end{array}$ & 76 & 'Niagara Rosada' spontaneous somatic mutation \\
\hline $\begin{array}{l}\text { 'Niagara Rosada sem Semente' } \\
\text { ('Seedless Rosy Niagara') }^{3}\end{array}$ & 38 & 'Niagara Rosada' spontaneous somatic mutation \\
\hline 'Niagara Steck' ('Steck Niagara') ${ }^{4}$ & 38 & 'Niagara Rosada' spontaneous somatic mutation \\
\hline $\begin{array}{l}\text { 'Niagara Variegada' ('Variegated } \\
\text { Niagara') }\end{array}$ & 38 & 'Niagara Rosada' spontaneous somatic mutation \\
\hline
\end{tabular}

Chromosome counts: ${ }^{1}$ Chromosome Counts Data Base (CCDB) http://ccdb.tau.ac.il/Angiosperms/Vitaceae/Vitis/;

${ }^{2}$ Nebel (1929); ${ }^{3}$ Pierozzi and Mura (2019); ${ }^{4}$ unpublished data. ${ }^{*}$ Pedigree source: Maul et al. (2021). 


\section{Cytological procedures}

Young inflorescences with flower buds at different stages of development were collected over three years in August 35-40 days after grapevine pruning. The flower buds were fixed in freshly prepared 3:1 Carnoy solution (3 parts of ethanol $99 \%: 1$ part of glacial acetic acid) and stored at $-20^{\circ} \mathrm{C}$ until cytological preparations. Anthers of fixed young buds were removed and squashed in $1.2 \%$ acetic carmine solution for cytological analyses. Since the tapetum development is closely related to the microsporogenesis progress, the analyses of the mitotic activity of the tapetal cells were carried out during the distinct meiotic phases from leptotene to tetrad as well as at young pollen grain phase. Knowing that the microsporogenesis is a dynamic and continuous process, it was decided to group the meiotic phases in five basic stages (Table 2) for comparison of tapetal cell mitotic activity. Fifteen slides of each twelve varieties were prepared and all the tapetal cells were counted on each slide and the percentage of tapetal cells mitotically active were calculated along with the standard deviation for each variety at each stage.

Table 2. Meiotic stages considered with the corresponding meiotic phases for the analyses of the mitotic activity of tapetal cells

\begin{tabular}{|l|c|}
\hline \multicolumn{1}{|c|}{ Stages } & Meiotic phases \\
\hline Le-P & From Leptotene to Pachytene \\
\hline M1 & From Diplotene to Telophase I \\
\hline M2 & From Prophase II to Telophase II \\
\hline IV & Tetrad \\
\hline Pollen & Young pollen grains \\
\hline
\end{tabular}

The ploidy level of each cell was determined by counting the chromosome number at late prometaphase or at metaphase for each variety and the percentage mean values of diploid and polyploid tapetal cells was calculated for each variety at each meiotic stage. Those cells with one diploid chromosome group $(2 n=38)$ were considered diploid tapetal cells. Polyploid cells were those with two or more separated diploid chromosome groups and those with one or more groups with 76 chromosomes each or more. In the spontaneous autotetraploid 'Niagara Rosada Gigante' $(2 n=4 x=76)$, diploid tapetal cells were those with only one diploid chromosome group $(2 n=76)$ and polyploid those cells with two or more separate diploid chromosome groups as well as those with one or more groups with 152 chromosomes or more. An average of 1,134 tapetal cells were scored on each slide analyzed and the mean percentage values were calculated along with the standard deviation for each variety at each stage.

Another set of fifteen slides of each variety were prepared by squashing the anthers in $45 \%$ acetic acid. The coverslips were removed after a brief bath in liquid nitrogen then slides were aged for a week and afterwards submitted to NOR-banding (Howell and Black, 1980) for nucleolus counting in the tapetal cells at interphase at different meiotic phases. Two thousand interphase cells were scored on each slide at each stage for each variety, and the number of nucleolus was scored in each cell for each variety and the mean percentage values were calculated along with the standard deviation.

The F-test (Pimentel-Gomes and Garcia, 2002) was applied to compare the mean percentage values obtained for tapetal cell mitotic activity, for diploid and polyploid tapetal cells and for the nucleolus number at each meiotic stage considered. Photomicrographs were taken using black and white 125 Ilford film in 'Olympus Vanox' photomicroscope. 


\section{Results}

\section{Mitotic activity}

It was witnessed that tapetal cells were abundant in the cytological preparations of the grapevine varieties studied. The softness of the cells noticed during the cytological preparations allowed its rupture and a satisfactory cell and chromosome spreading which avoided enzymatic pre-treatments. The mitotic activity was higher during microsporogenesis process at the Le-P stage, decreasing as the microsporogenesis moved forward IV stage (Figure 1) where the activity was lower with a prevalence of interphase cells with one large nucleus $(6 \mathrm{G})$, and at young pollen stage where no mitotic activity was seen, except for degenerated and amorphous tapetal cells (Figures 1 and $6 \mathrm{H}$ ).

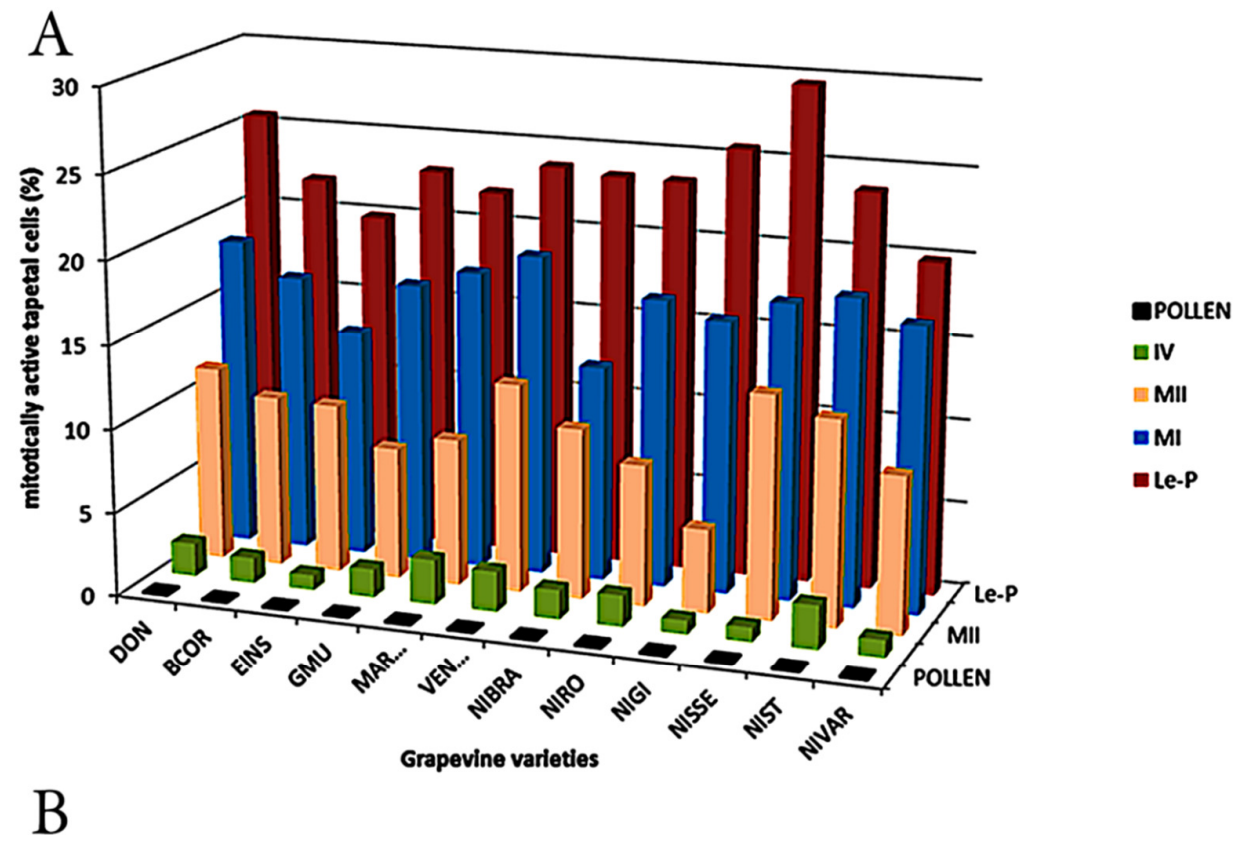

\begin{tabular}{|l|c|c|c|c|c|}
\hline \multirow{4}{*}{ \% Mitotic activity } & \multicolumn{5}{|c|}{ Meiotic stage } \\
\cline { 2 - 6 } & Le-P & MI & MII & IV & Pollen \\
\cline { 2 - 6 } & $23.45 \pm 1.92^{\mathrm{a}}$ & $16.86 \pm 1.89^{\mathrm{b}}$ & $\mathbf{9 . 9 6} \pm 2.31^{\mathrm{c}}$ & $1.66 \pm 0.43^{\mathrm{d}}$ & $\mathbf{0 . 0 0} \pm 0.00^{\mathrm{c}}$ \\
\hline
\end{tabular}

Figure 1. Mitotic activity in tapetal cells of $V$. vinifera seedless varieties 'A Dona'(DON), 'Black Corinth' (BCOR), 'Einset' (EINS), 'Golden Muscat' (GMU), 'Maria' (MAR), 'Venus' (VEN), and of 'Niagara' varieties 'Niagara Branca' (NIBRA), 'Niagara Rosada' (NIRO), 'Niagara Rosada Gigante' (NIGI), 'Niagara Rosada sem Semente' (NISSE), 'Niagara Steck' (NIST) and 'Niagara Variegada' (NIVAR) at five meiotic stages considered

(A) Graphic representation; (B) the mean percentage values with standard deviation. Mean values followed by different letters $=$ significant differences at $5 \%$ after F-test.

At the same time, during the ongoing microsporogenesis, an endomitotic process was notice in diploid tapetal cells at early meiotic stage (Le-P). Cells with one tetraploid chromosome group (Figure 2A, C, E and F, 3C, and 4A), cells with two or more separated diploid chromosome groups (Figure 2B, 3A, D, 4B, C and E, 6A) and cells with only one large polyploid chromosome group (Figure 3B and E) was observed at late prometaphase and at metaphase at different percentages (Table 3). In addition, cells showing only one diploid chromosome group were also seen (Table 3 and Figure 5). In the spontaneous autotetraploid 'Niagara Rosada Gigante' $(2 n=76$, Figure 2D) whole unbroken cells with tetraploid chromosome groups $(2 n=152)$ were hardly perceived (Figure 3F) and polyploid cells with more than 152 chromosomes were very rarely noted (Figure 3E). 
Cells with two or more separate diploid chromosome groups were spotted, yet in a fragmented state (Figure $6 \mathrm{~A})$. It is likely that the very low amount of unbroken polyploid tapetal cells could be due to the intensity of the press onto the slides and the coverslip to improve chromosome spreading for counting. Nevertheless, polyploid cells with more than five nuclei were solely viewed at interphase in this spontaneous autotetraploid variety (Figure 6F). It has very likely been the first time that the mitotic activity in the tapetal cells associated with meiotic stages of a plant with a high number of chromosomes as 'Niagara Rosada Gigante' was scored.

As the microsporogenesis advanced from Le-P to IV stage it was possible to observe a gradual decrease in the mean percentage values of diploid cells (from $28.20 \%$ to $13.38 \%$ ) and of polyploid cells with two or more individualized diploid chromosome groups, as well (from $44.53 \%$ to $19.40 \%$ ). On the other hand, an increase of the mean percentage values of polyploid cells with only one chromosome group (from $27.27 \%$ to $67.22 \%$ ) was perceived (Table 3 ).

Table 3. Mean percentage values of diploid and polyploid tapetal cells at prometaphase/metaphase at four meiotic stages considered*

\begin{tabular}{|l|c|c|c|}
\hline \multirow{2}{*}{$\begin{array}{c}\text { Meiotic } \\
\text { Stages }\end{array}$} & \multicolumn{2}{|c|}{ Percentage of some ploidy level in tapetal cells at prometafase/metaphase } \\
\cline { 2 - 4 } & Diploid & \multicolumn{2}{|c|}{ Polyploid } \\
\cline { 2 - 4 } & $\begin{array}{c}\text { Only one } 2 n \\
\text { chromosome group }\end{array}$ & $\begin{array}{c}\text { Two or more } 2 n \text { separate } \\
\text { chromosome groups }\end{array}$ & $\begin{array}{c}\text { Only one polyploid }(\mathrm{x} n) \\
\text { chromosome group }\end{array}$ \\
\hline Le-P & $28.20 \pm 3.04^{\mathrm{a}} \mathrm{A}$ & $44.53 \pm 3.16^{\mathrm{a}} \mathrm{B}$ & $27.27 \pm 3.10^{\mathrm{a}} \mathrm{A}$ \\
\hline M1 & $18.91 \pm 2.86^{\mathrm{b}} \mathrm{A}$ & $36.79 \pm 2.95^{\mathrm{b}} \mathrm{B}$ & $44.30 \pm 3.27^{\mathrm{b}} \mathrm{C}$ \\
\hline M2 & $15.81 \pm 2.45^{\mathrm{b}} \mathrm{A}$ & $29.70 \pm 2.73^{\mathrm{c}} \mathrm{B}$ & $54.49 \pm 2.97^{\mathrm{c}} \mathrm{C}$ \\
\hline IV & $13.38 \pm 3.71^{\mathrm{b}} \mathrm{A}$ & $19.40 \pm 3.37^{\mathrm{d}} \mathrm{A}$ & $67.22 \pm 4.09^{\mathrm{d}} \mathrm{B}$ \\
\hline
\end{tabular}

Diploid cells with only one diploid $(2 n)$ chromosome group, polyploid cells with two or more separate non-fused diploid groups (two or more $2 n$ separate chromosome groups), and cells with only one large polyploid (xn) chromosome group. Lower case letters = comparisons among the different meiotic stages. Capital letters = comparisons among the three different types of tapetal cells. Mean values followed by different letters = significant at $5 \%$ after F-test. Mean values followed by the same letters $=$ not significant at $5 \%$ after F-test. ${ }^{*}$ Young pollen stage was not included because tapetal cells at this stage were all degenerated.

The mean percentage values of diploid cells differed significantly between Le-P and M1, M2 and IV, though not among these last three stages (Table 3, lower case letters). Regarding the two types of polyploid tapetal cells, significant differences in mean percentage values were discerned during the four stages (Table 3 , lower case letters). Comparisons made in the same stage revealed significant differences between: (a) diploid cells and polyploid cells with two or more diploid separate chromosome groups from Le-P to M2 stages; (b) diploid cells and polyploid cells with one chromosome group from M1 to IV; and (c) polyploid cells with two or more diploid separate chromosome groups and those with only one polyploid group of chromosomes in all meiotic stages considered, i.e., from Le-P to IV stages (Table 3, capital letters).

Nevertheless, no significant differences were viewed between: (a) diploid and polyploid tapetal cells with one chromosome group at Le-P; and (b) diploid and those polyploid cells with two or more diploid separate chromosome groups at IV stage (Table 3, capital letters).

The high mean percentage value identified in polyploid tapetal cells with two or more individualized diploid chromosome groups in contrast to a lower mean value in cells with one polyploid chromosome group at Le-P, suggested that at this stage the process of chromosome group fusion was at the beginning.

In M2 stage, it was possible to see some polyploid cells at metaphase and anaphase with stickiness among chromosome groups displaying different shapes during this process (Figures $4 \mathrm{D}$ and F, 6C, D and E). At this stage, it was not possible to count the chromosome number due to its large amount, strong condensation state along with the stickiness. 




Figure 2. (A) 'Venus' tetraploid cell with 76 chromosomes; (B) 'Niagara Variegada' tetraploid cell with two separated diploid chromosome groups; (C) 'Maria' tetraploid cell with 76 chromosomes; (D) diploid cell $(2 n=76)$ of autotetraploid 'Niagara Rosada Gigante'; (E) 'Golden Muscat' tetraploid cell with 76 chromosomes; and (F) 'Niagara Variegada' tetraploid cell with 76 chromosomes

Photos: A, C, F prometaphase cells after acetic carmine squashing technique; B, D, E metaphase cells after NORbanding. Bar $=5 \mu \mathrm{m}$; arrows $=$ NOR sites. 

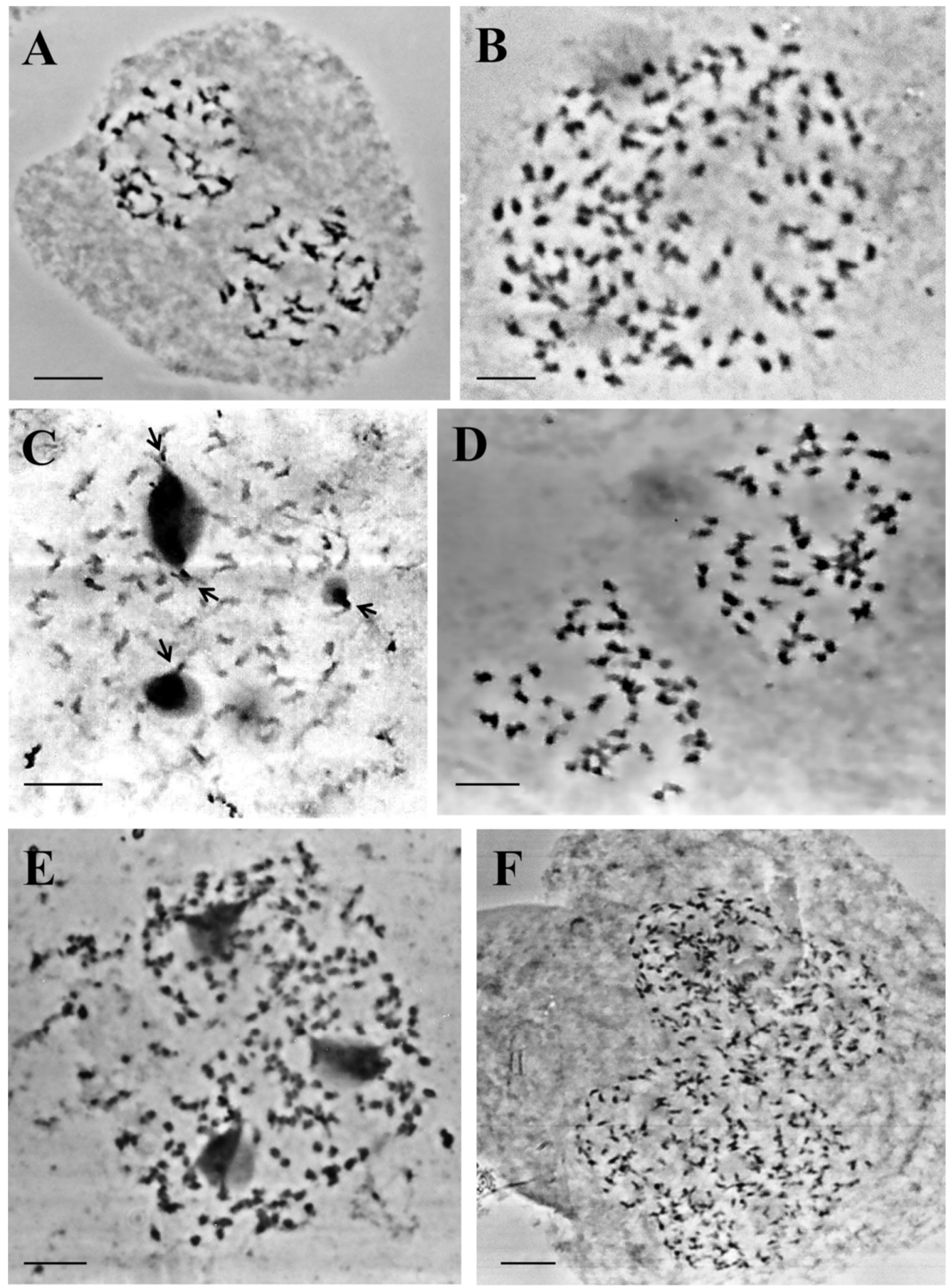

Figure 3. Tapetal cells of some grapevine varieties: (A) 'Black Corinth' with two diploid chromosome groups; (B) 'Venus' incomplete broken polyploid cell with 138 chromosomes; (C) 'Niagara Rosada' after NOR-banding with 76 chromosomes and three nucleoli; (D) 'Niagara Branca' with two diploid chromosome groups; spontaneous autotetraploid 'Niagara Rosada Gigante': (E) a very rare polyploid broken cell with a group of 152 chromosomes (on the right) and a group of 76 chromosomes (upper); and (F) with two overlapping tetraploid cells with 152 chromosomes each Arrows $=$ NOR sites. Bar $=5 \mu \mathrm{m}$ 

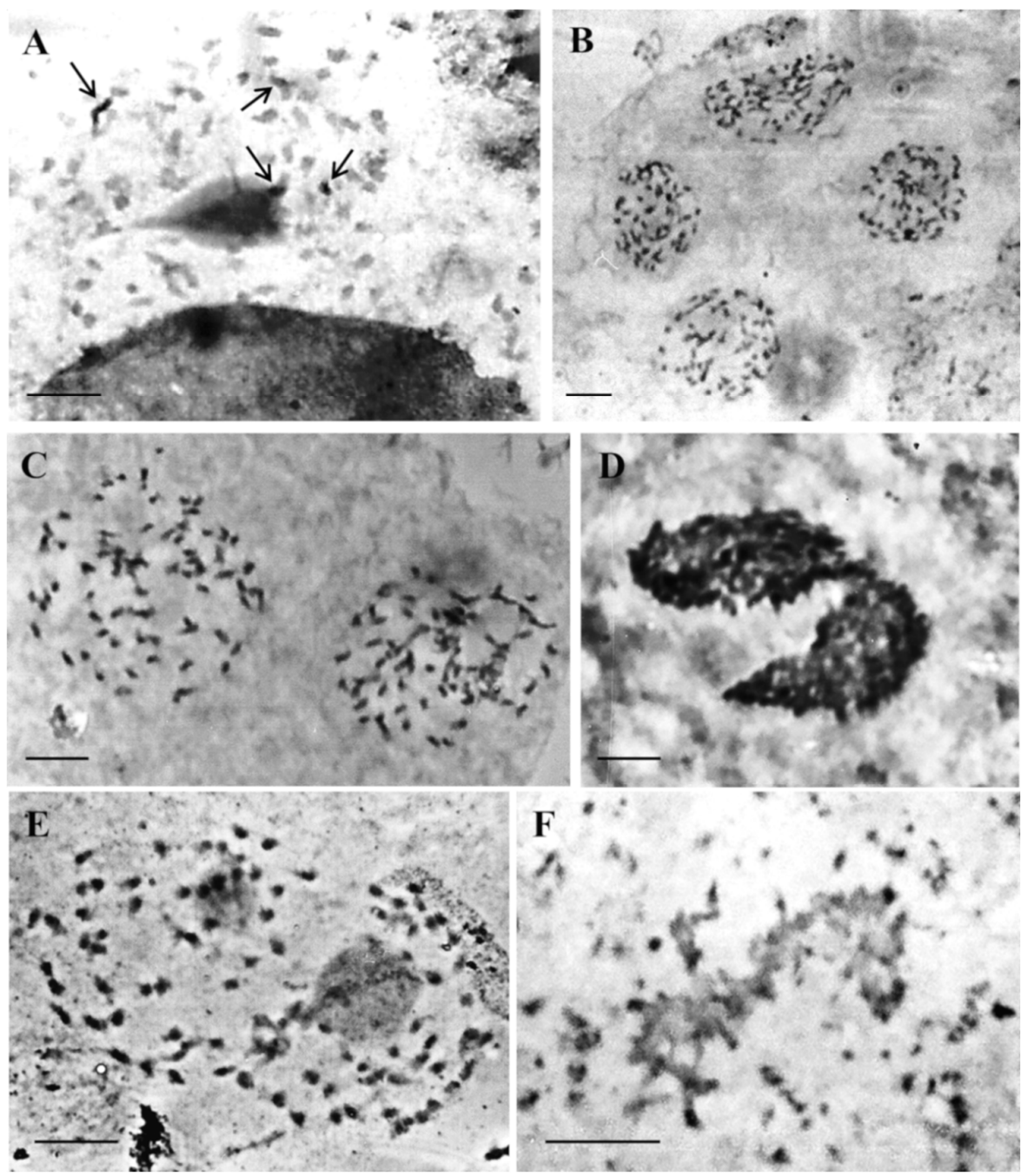

Figure 4. Tapetal cells of some grapevine varieties. (A) 'A Dona' tetraploid cell with 76 chromosomes after NOR-banding; 'Niagara sem Semente' polyploid cells with: (B) four diploid chromosome groups and (C) two diploid chromosome groups; (D) fusion process between two polyploid chromosome groups of 'Einset'; 'Niagara Steck': (E) polyploid cell with two diploid chromosome groups; and (F) after NORbanding showing fusion between two chromosome groups Bars $=5 \mu \mathrm{m} ; \mathrm{D}=10 \mu \mathrm{m} ;$ Arrows $=\mathrm{NOR}$ sites
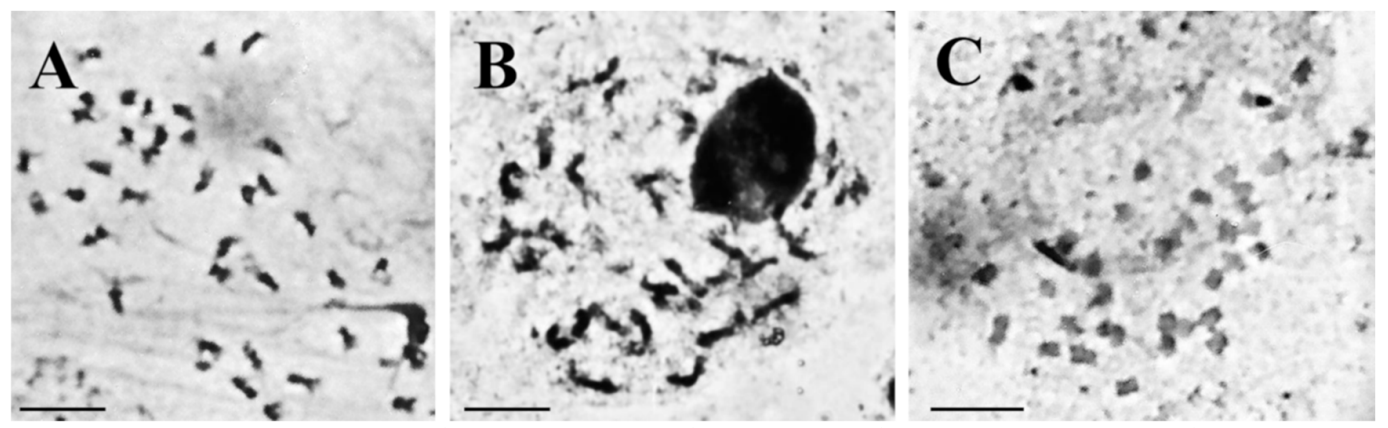

Figure 5. Diploid tapetal cells $(2 n=38)$ as seen in (A) 'A Dona'; (B) 'Black Corinth; and (C) 'Golden 'Muscat', for instance

A and B: after acetic carmine technique; C: after NOR-banding. Bars $=5 \mu \mathrm{m}$ 


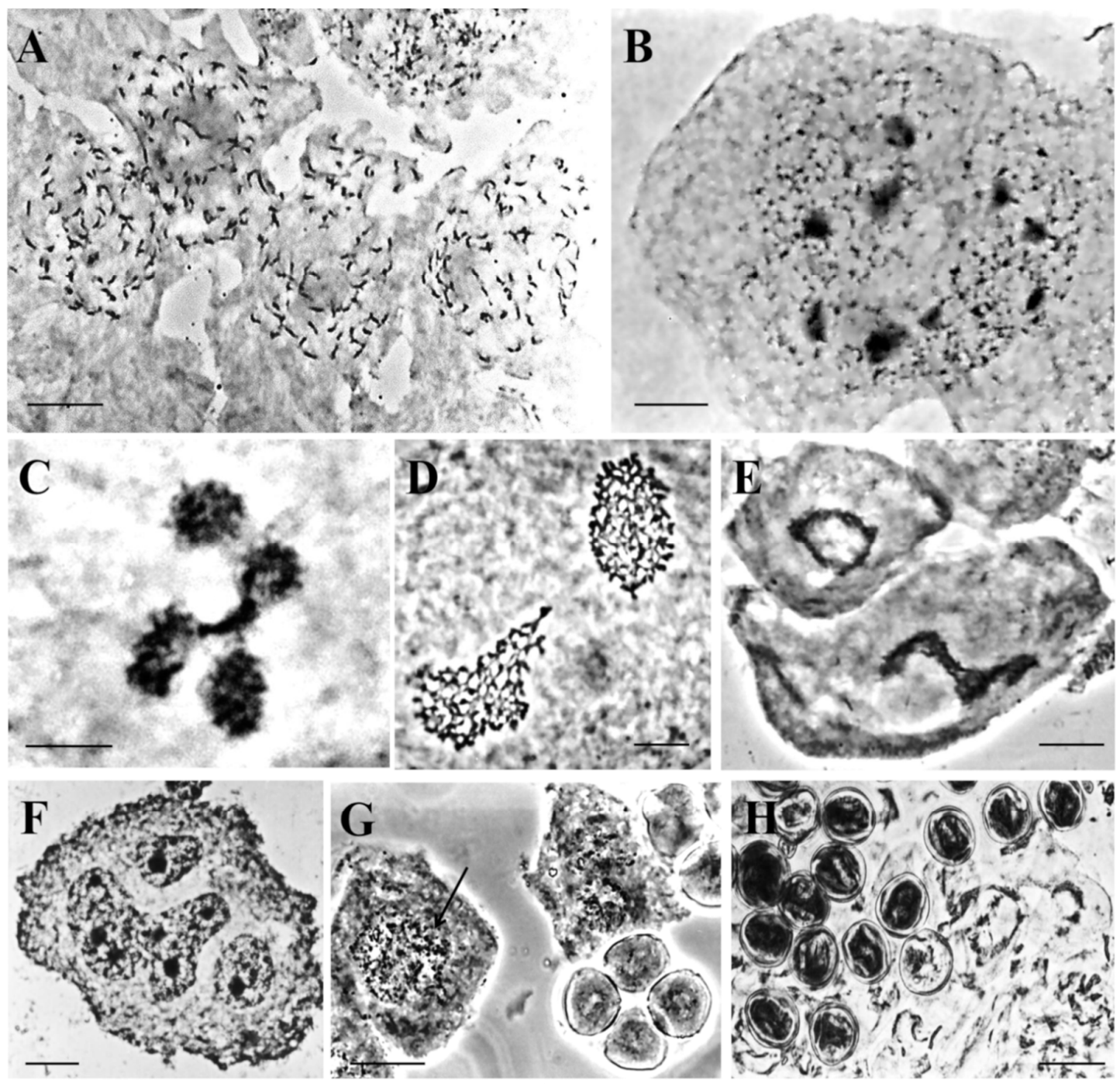

Figure 6. Tapetal cells of some grapevine varieties. (A) spontaneous tetraploid 'Niagara Rosada Gigante' at prometaphase showing a broken cell with four diploid $(2 n=76)$ groups of chromosomes; (B) 'Niagara Rosada sem Semente' with nine nucleoli after NOR-banding; (C) 'A Dona' with four chromosome groups with stickiness among them; (D) 'Einset' with two polyploid chromosome groups with stickiness; (E) 'Black Corinth' chromosome groups showing different shapes at the fusion process; (F) 'Niagara Rosada Gigante' at interphase with six nuclei some of them at the beginning of fusion process; $(G)$ 'Golden Muscat' interphase cell at IV stage with an enlarged nucleus (arrow); (H) 'Golden Muscat' degenerated tapetal cells at young pollen stage

Bars A to $\mathrm{F}=10 \mu \mathrm{m} ; \mathrm{G}=100 \mu \mathrm{m}$ and $\mathrm{H}=200 \mu \mathrm{m}$.

\section{Nucleolus number}

The use of NOR-banding was suitable to highlight the nucleolus that was sometimes difficult to distinguish after carmine squashing technique. One large and visible nucleolus was witnessed at prometaphase (Figure 4A, 5B). Two as well as three nucleoli were also seen in the same mitotic cell however in different sizes, i.e., a large one along with one or two smaller nucleoli (Figure 2D and E, 3C). Besides, NOR-banding also highlighted the NOR sites of chromosomes at late prometaphase and metaphase of some grapevine varieties (Figures 2B, 3C and 4A). 
Tapetal cells at interphase displayed a variable number of nucleolus visible after NOR-banding (Figures 6B and F, Table 4). The average percentage values of interphase cells displaying two or four nucleoli were the most common event (Figure 7) and cells with seven nucleoli appeared at a very low percentage. Interphase tapetal cells with eight and nine nucleoli were a rare event, only viewed in $0.04 \%$ of the cells analyzed at IV stage (eight nucleoli) and $0.06 \%$ of the cells analyzed at Le-P stage (nine nucleoli). Interphase cells with two nucleoli at Le-P stage showed the highest mean percentage value (49.01\%). However, at IV stage the mean percentage values of interphase cells showing one large nucleolus $(41.70 \%)$ was higher than cells with two $(27.04 \%)$ or four (19.21\%) nucleoli (Table 4).

Variations observed within the mean percentage of nucleolus number at interphase tapetal cells allowed two comparisons. One of them, considering the nucleolus number variation at the same meiotic stage (Table 4 , lower case letters) and the other regarding the variation in the mean percentage values of the same nucleolus number among the four meiotic stages (Table 4, capital letters).

Table 4. Mean percentage values with standard deviation of nucleolus number at interphase cells at each meiotic stage*

\begin{tabular}{|l|c|c|c|c|}
\hline \multirow{2}{*}{$N^{\circ} N U$} & \multicolumn{4}{|c|}{ Meiotic Stages } \\
\cline { 2 - 5 } & Le-P & M1 & M2 & IV \\
\hline 1 & $20.57 \pm 2.42^{\mathrm{a}} \mathrm{A}$ & $26.04 \pm 2.60^{\mathrm{a}} \mathrm{B}$ & $24.21 \pm 3.15^{\mathrm{a}} \mathrm{AB}$ & $41.70 \pm 2.94^{\mathrm{a}} \mathrm{C}$ \\
\hline 2 & $49.01 \pm 2.47^{\mathrm{b}} \mathrm{A}$ & $39.71 \pm 2.48^{\mathrm{b}} \mathrm{B}$ & $37.79 \pm 2.06^{\mathrm{b}} \mathrm{B}$ & $27.04 \pm 2.86^{\mathrm{b}} \mathrm{C}$ \\
\hline 3 & $10.19 \pm 1.93^{\mathrm{c}} \mathrm{A}$ & $7.13 \pm 1.55^{\mathrm{c}} \mathrm{A}$ & $7.88 \pm 1.98^{\mathrm{c}} \mathrm{A}$ & $7.71 \pm 1.80^{\mathrm{c}} \mathrm{A}$ \\
\hline 4 & $17.89 \pm 1.79^{\mathrm{a}} \mathrm{A}$ & $23.79 \pm 2.07^{\mathrm{a}} \mathrm{B}$ & $25.75 \pm 2.50^{\mathrm{a}} \mathrm{B}$ & $19.21 \pm 2.50^{\mathrm{d}} \mathrm{A}$ \\
\hline 5 & $1.61 \pm 0.47^{\mathrm{d}} \mathrm{A}$ & $2.33 \pm 0.76^{\mathrm{d}} \mathrm{A}$ & $3.04 \pm 1.30^{\mathrm{d}} \mathrm{A}$ & $3.25 \pm 1.20^{\mathrm{e}} \mathrm{A}$ \\
\hline 7 & $0.50 \pm 0.46^{\mathrm{eg}} \mathrm{A}$ & $0.83 \pm 0.68^{\mathrm{e}} \mathrm{A}$ & $1.25 \pm 0.79^{\mathrm{d}} \mathrm{A}$ & $0.88 \pm 0.93^{\mathrm{f}} \mathrm{A}$ \\
\hline 8 & $0.17 \pm 0.05^{\mathrm{e}} \mathrm{A}$ & $0.17 \pm 0.00^{\mathrm{e}} \mathrm{A}$ & $0.08 \pm 0.00^{\mathrm{e}} \mathrm{B}$ & $0.17 \pm 0.00^{\mathrm{f}} \mathrm{A}$ \\
\hline 9 & $0.00 \pm 0.00^{\mathrm{f}} \mathrm{A}$ & $0.00 \pm 0.00^{\mathrm{f}} \mathrm{A}$ & $0.00 \pm 0.00^{\mathrm{f}} \mathrm{A}$ & $0.04 \pm 0.00^{\mathrm{g}} \mathrm{B}$ \\
\hline
\end{tabular}

Lower case letters = comparison among the different nucleolus number at the same stage. Capital letters = comparison the same nucleolus number among the meiotic stages. Mean values followed by different letters = significant at $5 \%$ after F-test. Mean values followed by the same letters = not significant at $5 \%$ after F-test. *Young pollen stage was not included because tapetal cells at this stage were degenerated

Significant differences were discerned among the mean percentage values of interphase tapetal cells with: (a) one to three, five, six and eight nucleoli at Le-P and at M1 stages; (b) one to three, five, seven and eight nucleoli at M2 stage; an (c) one to six, eight and nine nucleoli at IV stage (Table 4, lower case letters). The differences between cells with one nucleolus and those with four nucleoli were not significant at Le-P, M1 and M2 stages (Table 4, lower case letters).

An accentuated decrease of the nucleolus number in tapetal cells at interphase was distinguished from cells with four to cell with five nucleoli onward in the four meiotic stages considered (Table 4, lower case letters and Figure 7). Besides, expressive lower mean percentage values of interphase cells with three nucleoli than with one, two and four was perceived.

When tapetal cells with the same number of nucleolus were compared among stages, significant differences were seen among Le-P and the following stages: (a) M1 to IV (two and nine nucleoli); (b) M1 and IV (one nucleolus); (c) M1 and M2 (four nucleoli); (d) M2 (seven nucleoli); and (e) IV (eight nucleoli). Significant differences were also observed among M1 stage and (a) M2 (seven nucleoli); and (b) IV (one nucleolus, two, four and eight nucleoli). Expressive differences were noticed in the mean percentage values of tapetal cells at M2 stage when compared to IV stage (one nucleolus, two, four, seven and eight nucleoli) (Table 4, capital letters). Overall, one stage differed remarkably from the others in at least four different nucleolus number. No meaningful differences were viewed among these stages considering cells with three, five and six 
nucleoli. Besides, not any notable difference was remarked involving the four stages at one time with the same nucleolus number.



Figure 7. Graphic representation of the mean percentage values (y-axis) of the nucleolus number ( $\mathrm{x}$-axis) scored at interphase tapetal cells of grapevine varieties from Le-P to IV stages. Young pollen stage was not included because tapetal cells at this stage were degenerated

\section{Discussion}

The softness of tapetal cells sighted in the grapevines studied may be related to its thinner and permeable cell wall and possibly to its single-layer nature, allowing for the rupture as well as rendering a satisfactory cell and chromosome spreading. According to Pacini (1997), the ease of cell wall break is a common feature of almost all parietal/secretory tapetum type. However, it is not a rule. In Arabidopsis thaliana, for instance, Weiss and Maluszynska (2001) observed that the secretory tapetum did not display a satisfactory chromosome spreading but tended to show clumped mitotic chromosomes, despite the low number $(2 n=10)$ even after the employment of an enzymatic pre-treatment before the anther squashing.

The significant mitotic activity viewed in the tapetal cells of grapevines studied during the first stages of microsporogenesis was followed by cell polyploidization through endomitotic cycles and according to Matsunaga et al. (2013) a common mechanism that promotes polyploidization in tapetum tissue.

Tapetal cells of grapevines suffered at least two endomitotic cycles resulting in two diploid (first cycle) and four diploid (second cycle) chromosome groups. Nevertheless, the cells may suffer more than two cycles as inferred from cells at interphase showing more than six individualized nuclei. The number of endomitotic cycles a tapetal cell can go through, depends on the material studied and does not seem related to the diploid chromosome number, if high or low, or to chromosome size. In Cymbidium aloifolium, $C$. devonianum and C. tigrinum $(2 n=40)$, for instance, at most two diploid chromosome groups at prometaphase and anaphase have been reported (Sharma et al., 2012), two diploid or two tetraploid chromosome groups at metaphase were noted in A. thaliana $(2 n=10)$ (Weiss and Maluszynska, 2001) and two to four nuclei were counted at interphase in Campsis radicans $(2 n=40)$ tapetal cells (Konyar and Dane, 2013). Though, in Eremurus himalaicus $(2 n=14)$ (Oksala and Therman, 1977) and Picris babylonica $(2 n=10)$ (Malallah et al., 1996) four diploid and more than six diploid chromosome groups, respectively, at metaphase were viewed in the same cell. 
In grapevines, besides the endomitosis in the tapetal cells, a fusion process involving two or more chromosome groups in the same cells may have also occurred. It seems that nuclear fusion is not a rare event in tapetum tissue and nuclear fusion involving two polyploid chromosome groups were also reported in tapetal cells of Solanum tuberosum (Avanzi, 1950), Senescio glaucus, Picris babylonica and Launaea mucronata as well (Malallah et al., 1996), for instance.

Endomitosis is a dynamic process that can be discerned through the different levels of ploidy, which a cell population can display at the same meiotic stage. However, the mechanism that triggers the endopolyploidization of tapetal cells through endomitosis, as in grapevines, is not fully understood. It is known that the impairing of cyclin B1 degradation leads to endomitosis in somatic cells of a transgenic line of Nicotiana tabacum as well as to the inhibition of phragmoplast/cell plate formation, a structure that builds a cell wall between the daughter cells at the end of mitosis (Weingartner et al., 2004; Smertenko, 2018). In addition, mutation in the GIG1/OSDI gene was reported to be involved in endomitosis process in Arabidopsis thaliana through the suppression of the cyclin degradation (Iwata et al., 2001; Matsunaga et al., 2013).

It is generally assumed that the process of endomitosis permits the continuous integrity of the tapetal monolayer (Feng and Dickinson, 2010) which otherwise would require additional energy and time (Leitch, 2000). It can also preserve its protective barrier function for PMCs and pollen grains as suggested by Frawley and Orr-Weaver (2015). Simultaneously it allows for the fulfilment of the secretory and nourishing function, shortly through a significant increase in gene-copy numbers, as rDNA genes, essential for the synthesis of enzymes, nutrients and components of pollen wall, which are important for pollen maturity and viability before the programmed cell death starts.

Nucleolus is a remarkable territory in the eukaryote nucleus with a dynamic structure in regards to activity, size, position and number (Kalinina et al., 2018). It is formed around the nuclear cluster of genes (rDNA) coding for rRNA which are localized at specific regions, the nucleolar organizer regions (NOR) in some chromosomes. It has been reported to be involved in abiotic and biotic plant stress response (Khan et al., 2014) while a rising number of reports have shown an association between nucleolus responses to virus infection (Taliansky et al., 2010).

The total nucleolus volume and size are mainly determined by the transcriptional activity of the rDNA genes (Kalinina et al., 2018). Considering the short lifespan of tapetum, its nourishment function, an intense nucleolar activity and raise in its number and enlargement of its size throughout the microsporogenesis phases is somehow expected. The nucleolus number at interphase tapetal cells may vary significantly according to the species regarded. Polyploid tapetal cells at interphase with two, four or five individualized nuclei inclusive of two nucleoli each were reported in two varieties of S. tuberosum (Avanzi, 1950) and in Hieracium amplexicaule (Gentcheff and Gustafsson, 1940) at metaphase I of meiosis, while cells counting up to eight individualized nuclei including two nucleoli each were seem in Crepis zacintha at tetrad stage (Battaglia, 1949). In addition, mononucleated interphase cells containing two nucleoli were identified in Scilla peruviana and Capsicum annuum at prophase I of meiosis (Testillano et al., 1993). Tapetal cells with a large nucleus containing a large nucleolus and cytoplasm with many ribosomes, characterize the tapetal cells of Brassica oleraceae at microspore stage (Murgia et al., 1991). Besides, a large nucleus harboring either one large nucleolus or several smaller nucleoli were noted in interphase tapetal cells of maize (Chebotaru, 2002) as well as in those of apple (Malus domestica) (Forino et al., 2003) at the free microspore stage and at tetrad stage, respectively.

In Nicotiana tabacum and Brassica napus, Solís et al. (2013) observed that as the microsporogenesis moves forward to tetrad, the number of tapetal cells showing smaller nucleoli increased as well as the amount of the methyl transferase 1 (MET1) enzyme. This enzyme is necessary for DNA methylation and this is associated to the onset of tapetal PCD. Therefore, a high number of small nucleoli in interphase tapetal cells, rather than a large one at tetrad stage, may be a sign that degeneration via PCD process has been triggered in the tapetum tissue. The prevalence of one or two large nucleolus in the great majority of interphase tapetal cells of grapevines studied at tetrad stage might be understood as an indicator that an eminent process of nucleolus fragmentation in smaller ones is about to start as part of the PCD process ending the cycle of secretory 
hyperactivity of this tissue. However, this subject needs more studies with the aim of more refined techniques that could lead to a satisfactory conclusion.

\section{Conclusions}

The observation concerning mitotic activity in the tapetal cells of grapevine varieties have broadened the knowledge of this tissue, up to now restricted to a description of its morphology. Cytological preparations through anther squashing technique followed up or not by the coverslip split-up from the slide, not only provided material for microsporogenesis analyses but also a substantial amount of well-spread tapetal cells with mitotic activity. Thus, demonstrating it is an interesting option for further advanced cytogenetic studies regarding the possibility of a direct physical localization for a desired DNA sequence specific to this tissue and concurrently a follow up the desirable sequence in meiotic chromosome pair during its segregation at meiosis. It is also an interesting alternative tissue for monitoring adult grapevines granting the unveiling of a possible undesirable aneuploidy and/or heterochromatin amplification, which might cause gene silencing mainly in those grapevines obtained from tissue culture. Even though the nucleolus number varied greatly among tapetal cells at interphase in the grapevine, there seems to be a limit to this variation, since cells with five or more occurred at a very low percentage.

\section{Authors' Contributions}

Both authors read and approved the final manuscript.

\section{Acknowledgements}

The authors wish to thank Mr. Diego Xavier, Mr. Luiz Carlos Aparecido dos Santos and Mr. Donizete Crispim for fieldwork in the grapevine collection.

\section{Conflict of Interests}

The authors declare that there are no conflicts of interest related to this article.

\section{References}

Avanzi MG (1950). Endomitosi e mitosi a diplocromosomi nello sviluppo delle cellule del tappeto di Solanum tuberosum L. [Endomitosis and mitosis with diplochromosomes during the development of the tapetal cells in Solanum tuberosum L.]. Caryologia 2(2):205-222. https://doi.org/10.1080/00087114.1950.10797139

Battaglia E (1949). Agglutinazione cromossomica ("stickiness") quale causa di eccezionali condizioni nucleari nelle cellule del tappeto di Crepis zacintha (L.) Babc. [Abnormal nuclear conditions induced by chromosome agglutination ("stickiness") in the tapetal cells of Crepis zacintha (L.) Babc.] Caryologia 1(2):248-268. https://doi.org/10.1080/00087114.1949.10797511

Branas M (1932). Sur la caryologie des Ampélideés. [About the caryology of Ampalideae]. Comptes Rendus de l'Académie des Sciences, sér. III, Sciences de la Vie 194:121-123. http://visualiseur.bnf.fr/CadresFenetre?O=NUMM3147\&M=pagination 
Brown SW (1949). Endomitosis in the tapetum of tomato. American Journal of Botany 36(10):703-716. https://doi.org/10.1002/j.1537-2197.1949.tb05324.x

Büyükkartal HN, Çölgeçen H, Marasal B (2005). Development of anther wall throughout microsporogenesis in Vitis vinifera L. cv. Çavus. International Journal of Agriculture \& Biology 7(4):616-620. http://www.ijabjass.org

Castro C, Carvalho A, Pavia I, Leal F, Moutinho-Pereira J, Lima-Brito J (2018). Nucleolar activity and physical location of ribosomal DNA loci in Vitis vinifera L. by silver staining and sequential FISH. Scientia Horticulturae 232:5762. https://doi.org/10.1016/j.scienta.2017.12.064

Chebotaru AA (2002). Tapetum: ultrastructural aspects. In: Batygina TB (Ed). Embryology of Flowering Plants: Terminology and Concepts, Vol. 1 Generative Organs of Flower. Science Publishers Inc., Enfield, pp 25-29. https://doi.org/10.1201/9781482279917

Chromosome Counts Data Base (CCDB) (2021). Vitis L. genus. Retrieved 2021 April 27 from http://ccdb.tau.ac.il/Angiosperms/Vitaceae/Vitis/

Cochetel N, Minio A, Massonnet M, Vondras AM, Figueroa-Balderas R, Cantu D (2021). Diploid chromosome-scale assembly of the Muscadinia rotundifolia genome supports chromosome fusion and disease resistance gene expansion during Vitis and Muscadinia divergence. Genes Genome Genetics 11(4):1-11. https://doi.10.1093/g3journal/jkab033

Dorsey MJ (1914). Pollen development in the grape with special reference to sterility. Bulletin 144. University of Minnesota, St Paul. Retrieved from the University of Minnesota Digital Conservancy, http://hdl.handle.net/11299/183965.

Feng X, Dickinson HG (2010). Tapetal cell fate, lineage and proliferation in the Arabidopsis anther. Development 137:2409-2416. https://doi.org/10.1242/dev.049320

Forino LMC, Andreucci AC, Del Tredici I, Felici C, Giraldi E, Tagliasacchi AM (2002). DNA methylation of tapetum cells during microsporogenesis in Malus domestica Borkh. Israel Journal of Plant Science 51(2):91-100. https://doi.org/10.1560/8THY-KOP8-4V15-QCHQ

Frawley LE, Orr-Weaver TL (2015). Polyploidy. Current Biology 25(9):R345-361. https://doi.org/10.1016/j.cub.2015.03.037

Gentcheff G, Gustafsson $\AA$ (1940). The balance system of meiosis in Hieracium. Hereditas 26(1-2):209-249. https://doi.org/10.1111/j.1601-5223.1940.tb03233.x

Ghimpu V (1929). Sur les chromosomes de Vitis, Medicago et Hordeum [About the chromosomes of Vitis, Medicago and Hordeum]. Comptes Rendus de l'Association des Anatomistes 1(1):243-247. https://gallica.bnf.fr/ark:/12148/bpt6k432673g f290.item

Hickey CC, Smith ED, Shanshan C, Conner P (2019). Muscadine (Vitis rotundifolia Michx., syn. Muscadinia rotundifolia (Michx.) Small): the resilient, native grape of the Southeastern U.S. Agricultura 9(6):1-13. https://doi.org/10.3390/agriculture9060131

Howell WM, Black DA (1980). Controlled silver-staining of nucleolus organized regions with a protective colloidal developer: a 1-step method. Experientia 36(8):1014-1015. https://doi.org/10.1007/BF01953855

Iwata E, Ikeda S, Matsunaga S, Kurata M, Yoshioka Y, Criqui M-R, ... Ito M (2011). GIGAS CELL1, a novel negative regulator of the anaphase-promoting complex/cyclosome, is required for proper mitotic progression and cell fate determination in Arabidopsis. The Plant Cell 23(12):4382-4393. https://doi.org/10.1105/tpc.111.092049

Khan A, Garbelli A, Grossi S, Florentin A, Batelli G, Acuna T, ... Barak S (2014). The Arabidopsis STRESS RESPONSE SUPRESSOR DEAD-box RNA helicases are nucleolar- and chromocenter-localized proteins that undergo stressmediated relocalization and are involved in epigenetic gene silencing. The Plant Journal 79(1):28-43. https://doi.org/10.1111/tpj.12533

Kalinina NO, Makarova S, Makhotenko A, Love AJ, Taliansky M (2018). The multiple functions of the nucleolus in plant development, disease and stress responses. Frontiers in Plant Science 09:132 https://doi.org/10.3389/fpls.2018.00132

Konyar ST, Dane F (2013). Anther ontogeny in Campsis radicans (L.) Seem. (Bignoniaceae). Plant Systematics and Evolution 299(3):567-583. https://doi.org/10.1007/s00606-012-0743-0

Kuliyev VM (2020). The study of polyploid mutant forms of grapes. Cytology \& Histology International Journal 4(1):16. https://medwinpublishers.com/CHIJ/CHIJ16000119

Lei X, Liu B (2020). Tapetum-dependent male meiosis progression in plants: increasing evidence emerges. Frontiers in Plant Science 10:1667 https://doi.org/10.3389/fpls.2019.01667 
Leitch AR (2000). Higher levels of organization in the interphase nucleus of cycling and differentiated cells. Microbiology and Molecular Biology Review 64(1):138-152.

https://doi.org./10.1128/mmbr.64.1.138-152.2000

Li D-D, Xue J-S, Zhu J, Yang Z-N (2017). Gene regulatory network for tapetum development in Arabidopsis thaliana. Frontiers in Plant Science 8:1559. https://doi.org/10.3389/fpls.2017.01559

Liu Z, Shi X, Li S, Hu G, Zhang L, Song X (2018). Tapetal-delayed programed cell death (PCD) and oxidative stressinduced male sterility of Aegilopis uniaristata cytoplasm in wheat. International Journal of Molecular Science 19:1708 https://doi.org/10.3390/ijms.19061708

Malallah GA, Afzal M, Attia TA, Abraham D (1996). Tapetal cell nuclear characteristics of some Kuwait plants. Cytologia 61(3):259-267. https://doi.org/10.1508/cytologia.61.259

Matsunaga S, Katagiri Y, Nagashima Y, Sugiyama T, Hasegawa J, Hayashi K, Sakamoto T (2013). New insights into the dynamics of plant cell nuclei and chromosomes. International Review of Cell and Molecular Biology 305:253-301. http://dx.doi.org/10.1016/B978-0-12-407695-2.00006-8

Maul E, Sudharma KN, Ganesh A, Hundemer M, Kecke S, Marx G, ... Brühl U (2021). Vitis International Variety Catalogue (VIVC). Julius Kühn-Institut - Federal Research Centre for Cultivated Plants (JKI), Institute for Grapevine Breeding - Geilweilerhof (ZR). Retrieved 2021 April 20 from https://www.vivc.de/index.php? $r=$ site\%2Findex.

Murgia M, Charzynska M, Rougier, Cresti M (1991). Secretory tapetum of Brassica oleraceae L.: polarity and ultrastructural features. Sexual Plant Reproduction 4(1):28-35. https://doi.org/10.1007/BF00194568

Nebel BR (1929). Chromosome counts in Vitis and Pyrus. The American Naturalist 63(685):188-189. https://doi.org/10.1086/280251

Oksala T, Therman E (1977). Endomitosis in tapetal cells of Eremurus (Liliaceae). American Journal of Botany 64(7):866-872. https://doi.org/10.1002/j.1537-2197.1977.tb11929.x/

Olmo HP (1937). Chromosome numbers in the European grape (Vitis vinifera). Cytologia 2:606-613. https://doi.org/10.1508/cytologia.Fujiijubilaei.606

Ono S, Liu H, Tsuda K, Fukai E, Tanaka K, Sasaki T, Nonomura KI (2018). EAT1 transcription factor, a non-cellautonomous regulator of pollen production, activates meiotic small RNA biogenesis in rice anther tapetum. Public Library of Science (PLOS) Genetics 15(3):e1008033. https://doi.org/10.1371/journal.pgen.1008033

Pacini E (1997). Tapetum character states: analytical keys for tapetum types and activities. Canadian Journal of Botany 75(9):1448-1459. https://doi.org/10.1139/b97-859

Patel GI, Olmo HP (1955). Cytogenetics of Vitis. I. The hybrid V. vinifera X V. rotundifolia. American Journal of Botany 42(2):141-159. https://doi.org/10.1002/j.1537-2197.1955.tb11106.X

Patil SG, Patil VP (1992). Karyomorphology of Vitis vinifera, V. rotundifolia and their hybrid. Cytologia 57(1):91-95. https://doi.org/10.1508/cytologia.57.91

Pierozzi NI (2011). Karyotype and NOR-banding of mitotic chromosomes of some Vitis L. species. Revista Brasileria de Fruticultuta 1:564-570. https://doi.org/10.1590/S0100-29452011000500077

Pierozzi NI, Moura MF (2019). Cytological investigation in two mutants of the hybrid grapevine 'Niagara'. Notulae Botanicae Horti Agrobotanici Cluj-Napoca 47(3):913-920. https://doi.org/10.15835/nbha47311470

Pimentel-Gomes F, Garcia CH(2002). Estatística aplicada a experimentos agronômicos e florestais [Statistics applied to agronomic and forestry experiments]. FEALQ, Piracicaba.

Pinto-Maglio CAF, Pommer CV, Pierozzi NI (2010). Giemsa staining and fluorescent chromosome banding in some Vitis L. species. Caryologia 63(4):339-348. https://doi.org/10.1080/00087114.2010.10589744

Quilichini TD, Douglas CJ, Samuels AL (2014). New views of tapetum ultrastructure and pollen exine development in Arabidopsis thaliana. Annals of Botany 114(6):1189-1201. https://doi.org/10.1093/aob/mcu042

Raj AS, Seethaiah L (1969). Karyotype analysis and meiosis studies in three varieties of grape (Vitis vinifera L.). Cytologia 34(3):475-483. https://doi.org/10.1508/cytologia.34.475

Raj AS, Seethaiah L (1973). Cytological studies in grape (Vitis vinifera L.). Cytologia 38(4):549-557. https://doi.org/10.1508/cytologia.38.549

Sharma SK, Kumaria S, Tandon P, Rao SR (2012). Endomitosis in tapetal cells of some Cymbidiums (Orchidaceae). The Nucleus 55(1):21-25. https://doi.org/10.1007/s13237-012-0049-1

Shetty BV, Raman VS (1960). Chromosome numbers in Vitaceae. Current Science 29(7):279-280 https://www.jstor:org/stable/24214346 
Smertenko A (2018). Phragmoplast expansion: the four-stroke engine that powers plant cytokinesis. Current Opinion in Plant Biology 46:130-137. https://doi.org/10.1016/j.pbi.2018.07.011

Solís MT, Chakabarti N, Corredor E, Cortés-Eslava J, Rodríguez-Serrano M, Biggiogena, ... Testillano OS (2013). Epigenetic changes accompany developmental programmed cell death in tapetum cells. Plant and Cell Physiology 55(1):16-29. https://doi.org./10.1093/pcp/pct152

Takusagawa H (1952). Chromosome numbers of the Vitaceae. Japanese Journal of Genetics 27(1-2):22-24. https://doi.org/10.1266/jjg.27.22

Taliansky ME, Brown JWS, Rajamäki ML, Valkonen JPT, Kalinina NO (2010). Involvement of the plant nucleolus in virus and viroid infections: parallels with animal pathosystems. Advances in Virus Research 77:119-158. https://doi.org/10.1016/B978-0-12-385034-8.00005-3

Testillano P, Gonzalez-Melendi S, Fado B, Sanchez-Pena A, Omedilla A, Risueño MC (1993). Immunolocalization of nuclear antigens and ultrastructural cytochemistry on tapetal cells of Scilla peruviana and Capsicum annuum. In: Hesse H, Pacini E, Willensen M (Eds). The Tapetum: Cytology, Function, Biochemistry and Evolution. Plant Systematics and Evolution Supplementum 7 Springer-Verlag, Wien, pp 75-90. https://doi.org/10.1007/978-37091-6661-1_7

The Plant List (2013). Version 1.1. Published on the Internet. Retrieved 2021 May 03 from http://www.theplantlist.org/

Viljoen TA, Spies JJ (1995). Cytogenetical studies of three Vitis species. Vitis 34(4):221-224. https://doi.org/10.5073/vitis.1995.34.221-224

Weingartner M, Criqui M-C, Mészáros T, Binarova P, Schmit A-C, Helfer A, ... Genschik P (2004). Expression of a nondegradable cyclin B1 affects plant development and leads to endomitosis by inhibiting the formation of a phragmoplast. The Plant Cell 16(3):643-657. https://doi.org/10.1105/tpc.020057

Weiss H, Maluszynska J (2001). Molecular cytogenetic analysis of polyploidization in the anther tapetum of diploid and autotetraploid Arabidopsis thaliana plants. Annals of Botany-London 87(6):729-735. https://doi.org/10.1006/anbo.2001.1402

Witkus ER (1945). Endomitotic tapetal cell divisions in Spinacia. American Journal of Botany 32(6):326-330. https://doi.org/10.2307/2437165

Zhai J, Zhang H, Arikit S, Huang K, Nan G-L, Walbot V, Meyers BC (2015). Spatiotemporally dynamic, cell-type dependent premeiotic and meiotic phasiRNAs in maize anthers. Proceedings of the National Academy of Science of the United States of America 112(10):3146-3151. https://doi.org/10.1073/pnas.1418918112

Zheng H, Yu X, Yuan Y, Zhang Y, Zhang Z, Zhang J, ...Tao J (2016). The VviMYB8O gene is abnormally expressed in Vitis vinifera L. cv. 'Zhong Shan Hong' and its expression in tobacco driven by the $35 \mathrm{~S}$ promoter causes male sterility. Plant and Cell Physiology 57(3):540-557. https://doi.org/10.1093/pcp/pcw011
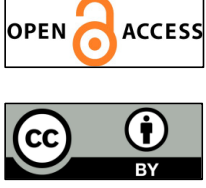

The journal offers free, immediate, and unrestricted access to peer-reviewed research and scholarly work. Users are allowed to read, download, copy, distribute, print, search, or link to the full texts of the articles, or use them for any other lawful purpose, without asking prior permission from the publisher or the author.

License - Articles published in Notulae Botanicae Horti Agrobotanici Cluj-Napoca are Open-Access, distributed under the terms and conditions of the Creative Commons Attribution (CC BY 4.0) License.

(c) Articles by the authors; UASVM, Cluj-Napoca, Romania. The journal allows the author(s) to hold the copyright/to retain publishing rights without restriction. 